\title{
HOLOCENE VEGETATION HISTORY FROM KING RIVER RAILWAY BRIDGE, WESTERN TASMANIA
}

\author{
by Guus van de Geer, Sean J. Fitzsimons and Eric A. Colhoun \\ (with three text-figures)
}

\begin{abstract}
VAN DE GEER, G., FITZSIMMONS, S.J. AND COLHOUN, E.A., 1991 (20:xii): Holocene vegetation history ftom King River Railway Bridge, western Tasmania. Pap. Proc. R. Soc. Tasm. 125: 73-77. https://doi.org/10.26749/rstpp.125.73 ISSN 0080-4703. Department of Geography and Environmental Studies, University of Tasmania, Box 252C GPO, Hobart, Tasmania, Australia 7001 (GvdG); Department of Geography, University of Otago, PO Box 56, Dunedin, New Zealand (SJF); and Department of Geography, University of Newcastle, Shortland, New South Wales, Australia 2308 (EAC).
\end{abstract}

\begin{abstract}
Pollen analysis of a sequence of post-glacial deposits north of the old railway bridge over the King River showed that cold wet heath, with Microstrobos and Epacridaceae, and herbland of Gramineae, Compositae and Astelia occurred in the King Valley before ca. $13000 \mathrm{yr}$ BP. Temperate rainforest/wet mixed forest developed after $13000 \mathrm{yr} \mathrm{BP}$ and was dominated by Phyllocladus before ca. $6400 \mathrm{yr}$ BP. Between ca. 6400 and $4000 \mathrm{yr}$ BP Nothofagus and Eucalyptuswere co-dominant. A hiatus in deposition of organic-rich sediments occurred between 4000 and $2500 \mathrm{yr}$ BP, when slope debris/alluvial fan gravels were formed. After $2500 \mathrm{yr}$ BP Phyllocladus became dominant again. A mosaic of shrub, heath, sedge and herb communities occurred in addirion to the rainforest/wet mixed forest vegetation during much of the post-glacial period. These communities seem to reflect variations in habitat and environmental conditions related to soil differences, flooding, waterlogging and burning adjacent to the King River. The pollen sequence shows the characteristic early post-glacial peak of P'byllocladus, the early-middle p•stglacial maximum of Pomaderris and the middle Holocene maximum of Nothofagus for western Tasmania. The vegetation was influenced by burning at all times. The climate transition from cold to cool humid conditions occurred around $13000 \mathrm{yr}$ BP and was probably relatively rapid.
\end{abstract}

Key Words: Holocene, palynology, Tasmania, vegetation history

\section{INTRODUCTION}

A roadside section west of Crotty Road and $500 \mathrm{~m}$ north of the old railway bridge over the King River exposed a sequence of alluvial sand and gravel, organic silt, slope/alluvial fan deposits and peaty soil overlying glacial sands and gravels (fig. 1). The exposure occurred beside a Hydro Electric Commission marker post labelled K55 at grid reference 882321 on the Franklin 1:100 000 scale Topographic Survey map. The glacial deposits were known to be outwash of Henty Glaciation age (i.e. Penultimate Glaciation) (Fitzsimons 1988). The section attracted attention because it was not known if the surface peaty soil represented the Holocene, with the slope/alluvial fan deposits and underlying silts being of last or Margaret Glaciation age, or whether they were all of Holocene age. The stratigraphy of the section was studied in the field. The silt and peat deposits were analysed for pollen, and wood samples from the base of the peat and within the silts were dated by radiocarbon to determine the age of the deposit. This paper reports the results of these investigations.

\section{ENVIRONMENT}

The site occurs at $200 \mathrm{~m}$ altitude adjacent to the Thureau Hills on the western side of the King Valley. It is underlain by Ordovician Crotty Quartzite which forms the footslopes of the Thureau Hills that consist mainly of Owen Conglomerate. The quartzite is mantled by Henty age outwash sands and gravels and, in places, by slope and alluvial fan deposits (Colhoun \& Fitzsimons 1990).

The climate is wet and cloudy, with approximately $2500 \mathrm{~mm}$ precipitation distributed all year round by the maritime westerly winds. Mean temperatures at
Queenstown, the nearest recording station, are $15.5^{\circ} \mathrm{C}$ for February and $7.1{ }^{\circ} \mathrm{C}$ for July. Snow, frost and valley fogs caused by cold air drainage are common in winter.

The natural vegetation of the region is potentially temperate rainforest but the vegetation has been extensively altered by the effects of firing, logging and mining (Kirkpatrick 1977). At the site, the surface vegetation consists of burnt Melaleuca and Leptospermun scrub, and of Epacridaceae (mainly Sprengelia incarnata) and Gymnoschoen us sphaerocephalus wet heath.

\section{STRATIGRAPHY AND DATING}

The stratigraphy (fig. 2) shows:

$0-0.53 \mathrm{~m}$ - sandy blanket peat with fibrous roots and occasional wood fragments;

0.53-0.90 m - well-sorted, grey angular pebble gravel with coarse sand matrix - gravel derived from glacial deposits; 0.90-1.70 m - organic silt with wood fragments; $1.70-1.85 \mathrm{~m}$ - rounded pebble gravel; $1.85+\mathrm{m}$ - grey fine sand.

The stratigraphy is interpreted as Holocene blanket peat forming from local heath and bog plants on a gravel deposit of slope/alluvial fan origin. Below the gravel, silt with drifted wood fragments was deposited on a damp surface adjacent to a stream or in a shallow pond. The gravels and sand at the base are alluvial.

Two samples of wood were taken for radiocarbon dating from $0.50 \mathrm{~m}$ and $1.30 \mathrm{~m}$ depths. The results gave ages of $2520 \pm 80 \mathrm{yr} \mathrm{BP}$ (SUA2597) and $7690 \pm 90 \mathrm{yr} \mathrm{BP}$ (SUA2770) respectively and confirmed the age of the sequence as Holocene. This indicates that the slope/alluvial fan deposits were formed during middle to late Holocene times. 

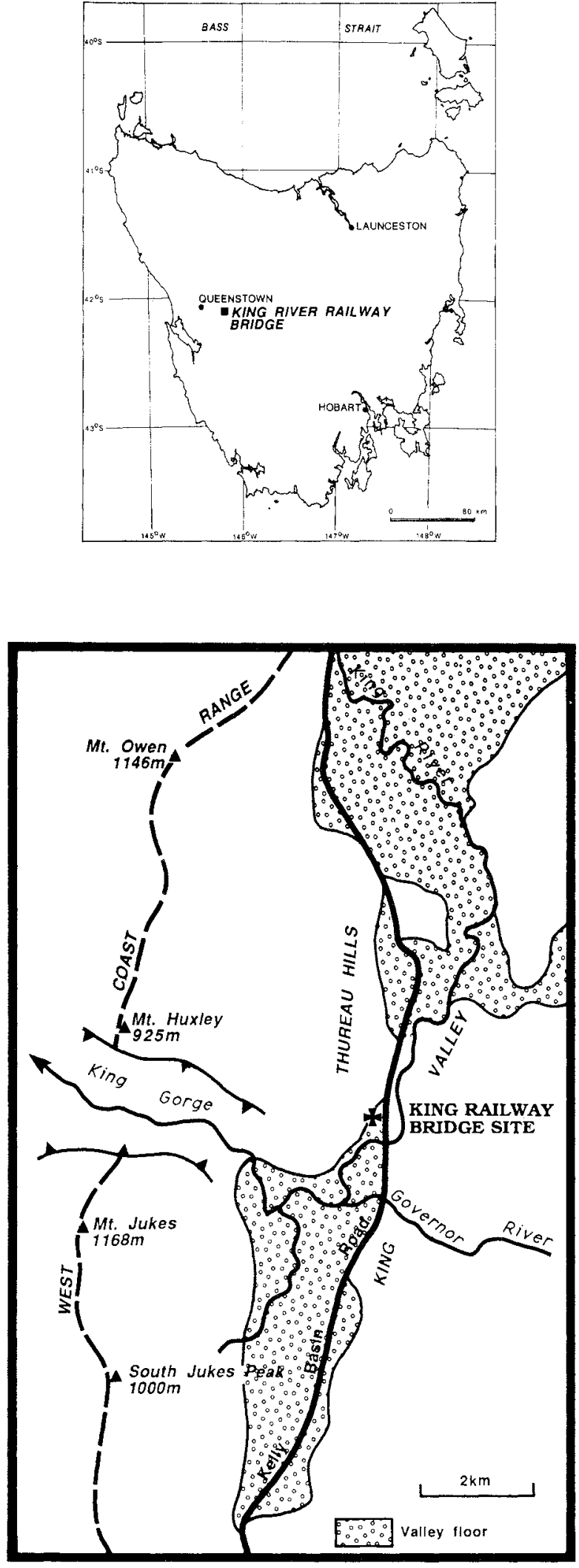

Fig. 1 - Location of King River Bridge site.

\section{POLLEN ANALYSIS}

Samples of the peat and organic silt were taken at $50 \mathrm{~mm}$ intervals for pollen analysis and prepared using the Faegri \& Iversen (1975) method. A sum of at least 300 grains of all terrestrial taxa, excluding sedges and ferns, was used for calculating the curves of the relative pollen diagram (fig. 2). Since inclusion of all terrestrial taxa in the pollen sum emphasises the importance of local taxa at the expense of regional components of the vegetation in relative diagrams, the values were also calculated to include only the most important taxa in the regional pollen rain as indicated by Macphail $(1975,1979)$ for figure 3 . The forms of the pollen curves for local taxa are approximately the same by both methods of calculation, so they have only been presented once in figure 2. The plant nomenclature follows Curtis (1963, 1967), Curtis \& Morris (1975), Wakefield (1975) and Willis (1970). Charcoal fragments over $20 \mathrm{~mm}$ diameter were counted and calibrated against known quantities of introduced Lycopodium clavatum spores (Stockmarr 1971).

\section{THE POLLEN DIAGRAM: DESCRIPTION AND INTERPRETATION}

The relative pollen diagram can be divided into four zones KRB 1 to KRB4:

ZONE KRB1, 0-0.53 m, characterised by Phyllocladus aspleniifolius, Eucalyptus and Nothofagus cunninghamii with Lagarostrobos franklinii, Agastachys odorata, Monotoca and Tasmannia lanceolata.

ZONE KRB2, 0.9-1.2 m, characterised by Nothofagus cunninghamii, Eucalyptuswith Bauera rubioides, Epacridaceae, Boronia and Melaleuca, plus Monotoca and Agastachys in upper part of zone.

ZONE KRB3, 1.2-1.6 m, characterised by Phyllocladus aspleniifolius, Nothofaguscunninghamii, Casuarina, Melaleuca and Gramineac.

ZONE KRB4, 1.6-1.7 m, characterised by Epacridaceae, Microstrobos niphophilus, Gramineae, Compositae and Astelia alpina.

The most important pollen taxa in Zone KRB4 are Epacridaceae, Microstrobos, Gramineae, Compositae, Astelia alpina and Restionaceae. Pollen of all taxa occur in sufficiently high percentages as to indicate local presence. The vegetation was clearly dominated by small shrubs and herbs. It is unlikely that many trees were present, as Nothofagus, Phyllocladus, Casuarina and Melaleuca can all occur as shrubs.

Pollen Zone KRB3 is dominated by Phyllocladus with abundant Epacridaceae and Melaleuca. In addition, Nothofagus, Eucalyptus and Leptospermum occur in substantial quantities throughout the zone. Casuarina and Pornaderris have distinct maxima in the lower part of the zone while Bauera expands in the upper part. Gramineae and Compositae decline throughout the zone. Restionaceae and Cyperaceae attain peaks early in the zone and decrease upwards. Pollen of alpine and subalpine taxa are so low that presence of the plants on site is unlikely. The vegetation would appear to have consisted of mainly trees and shrubs with a subsidiary herb component.

Pollen Zone KRB2 is dominated by Nothofagus with large quantities of Eucalyptus and Phyllocladus. Epacridaceae and Melaleuca form large components of the pollen assemblage that also includes notably Agastachys, Bauera, 


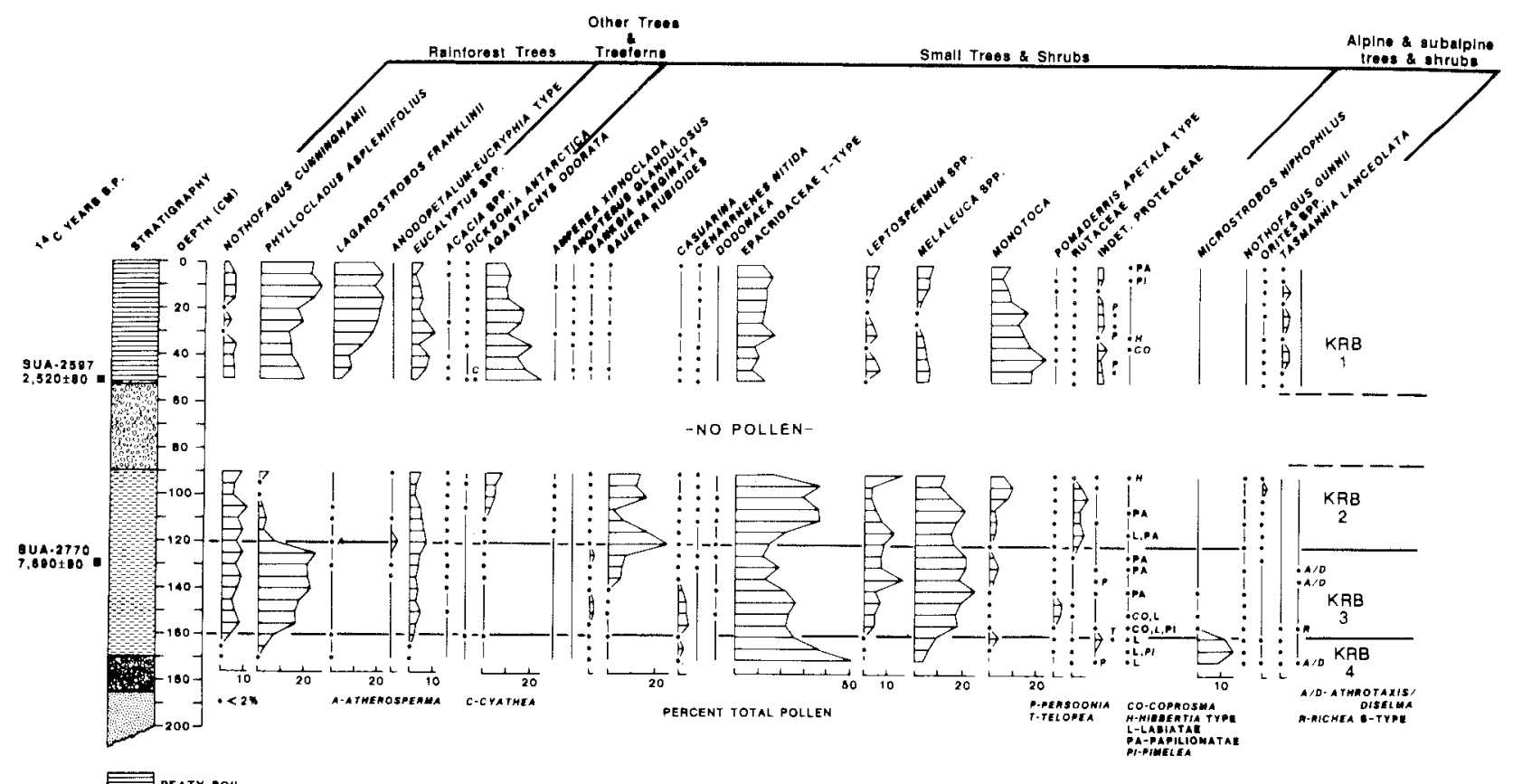

Fig. 2 - Stratigraphy of King River Bridge site.

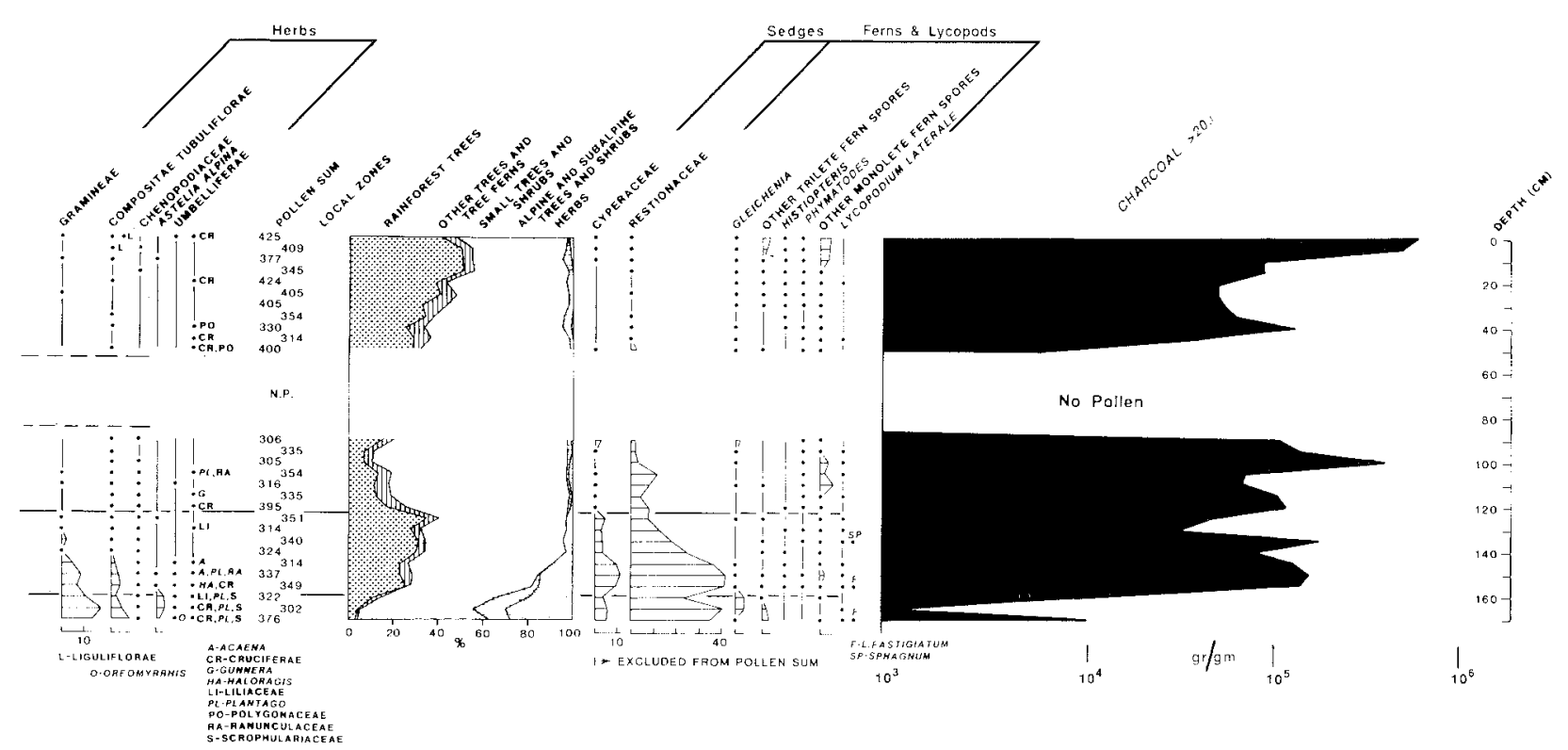

Fig. 3 - Relative pollen diagram.

Leptospermum, Monotoca and Rutaceae (cf. Phebalium squameum and Boronia). Except for Restionaceae few sedges, herbs or alpine and subalpine taxa are represented. The vegetation apparently consisted predominantly of mature forest trees, and of understorey tree and shrub taxa.

Pollen Zone KRB1 differs from Zone KRB2 by the reexpansion of Phyllocladus to dominance and reduction in Nothofagus while Eucalyptus maintains similar quantities. Lagarostrobos, Agastachys and Monotoca have high pollen values which indicate considerable local presence of these tree and shrub taxa. The sclerophyll shrub taxa Epacridaceae, Leptospermum and Melaleuca are much lower than in KRB2. Proteaceae and Tasmannia are present in moderate amounts for the first time. The vegetation appears to have been composed of forest tree taxa and a relatively diverse shrub flora.

The vegetation of Zone KRB4 is interpreted as representing the development of alpine heath and herbland on the floor of the King Valley in late glacial times. The heathland was characterised by the presence of considerable 
quantities of the endemic alpine conifer Microstrobos amongst, presumably, a variety of epacrids, while the herbland was dominated by grasses and composites. The presence of the alpine/subalpine Astelia also indicates cold wet habitat conditions. Casuarina, probably the shrub $C$. monilifera, was present in the heath but no other trees were necessarily present. Restionaceae was probably present in the heath and adjacent to the river bank or lake margin.

The inferred vegetation of this pollen assemblage zone is similar to that recorded at other sites in western Tasmania immediately succeeding the period of deglaciation (Macphail 1979, Colhoun et al. 1991a). The sediment probably commenced accumulating in the late glacial (i.e. $14-10 \mathrm{ka}$ $\mathrm{BP})$ but the age of the upper boundary is not known. However, at Governor Bog, $2 \mathrm{~km}$ south of the King River Railway Bridge site, where an attenuated late glacial sequence was recorded, the end of the alpine conifer Microstrobos phase was dated at $13020 \pm 130 \mathrm{yr}$ BP (SUA 2723). The proximity of the sites and the abrupt termination of Microstrobos, along with changes in associated taxa in both diagrams, suggest that the event was synchronous (Colhoun et al. 1991a). Thus, it appears that the KRB4/3 zone boundary is approximately 13000 years old and reflects an alteration from cold alpine to temperate vegetation and climatic conditions.

The vegetation of Zone KRB3 represents the phase of early Holocene rainforest/wet mixed forest expansion. The Phyllocladus "bulge" is very well represented and is a noted feature of early post-glacial pollen diagrams from western Tasmania (Macphail 1983); it is usually accompanied by a Pomaderris peak indicating the development of understorey taxa in the wet forests. The peak of Casuarina in the lower part of the zone, together with large quantities of Epacridaceae, Melaleuca and Restionaceae, indicate that rainforest/wet mixed forest with Eucalyptus had not yet fully developed during deposition of the lower part of the zone but the decrease in Epacridaceae and Restionaceae up through the zone suggests that forest vegetation was expanding. To what extent the Melaleuca, Epacridaceae and Restionaceae values reflect the co-occurrence of scrub, heath and sedge communities as a mosaic within the developing wet forests is difficult to judge but, given the location of the site adjacent to a major river, where forest development could be limited locally by flooding, waterlogging or the effects of fire, such complexity of structure is likely. The composition and inferred structure of the vegetation indicates that the climate must have been cool and humid throughout KRB3 rime.

The age of Zone KRB3 has not been precisely determined, as only one wood sample was dated at $130 \mathrm{~cm}$ to $7690 \pm 90$ yr BP (SUA 2770). If the lower boundary estimate of $13000 \mathrm{yr} \mathrm{BP}$ is correct and if reasonably continuous sedimentation occurred at the site, then the upper boundary would have an age of about $6400 \mathrm{yr}$ BP. While unlikely to be precise, such an estimate is consistent with the known range of the Phyllocladus "bulge" in western Tasmania, which generally precedes 7000 yr BP (Macphail 1979, Colhoun et al. $1991 \mathrm{a}$, Colhoun, pers. comm.).

During Pollen Zone KRB2, Nothofagus and Eucalyptus both became more important than Phyllocladus in the regional pollen flora and presumably also local vegetaion (fig. 3). The data suggest the development of a wet mixed forest with a diverse understorey that includes notably Pomaderris, Bauera, Monotoca, Rutaceae (mainly Phebalium squameum) and Agastachys. However, these taxa are accompanied by relatively high values for Rutaceae (cf. Boronia) and Orites, and very high values for Epacridaceae, Melaleuca and Leptospermum which show that scrub and heath taxa were important components of the local vegetation. In addition, moderate quantities of Cyperaceae and Restionaceae indicate the common occurrence of sedges. The pollen assemblage of Zone KRB2, therefore, suggests that the vegetation near the site probably consisted also of scrub, heath and sedge communities, perhaps in a strongly mosaiced pattern related to the local topography and poor drainage conditions adjacent to the King River.

The age of Zone KRB2 is certainly younger than $7690 \pm$ $90 \mathrm{yr}$ BP (SUA 2770) and probably younger than $6400 \mathrm{yr}$ $\mathrm{BP}$. The zone was truncated before $2520 \pm 80$ yr BP (SUA 2597). Extrapolation from $7690 \pm 90 \mathrm{yr} \mathrm{BP}$, on the basis of uniform sedimentation rate for the silt, would suggest an age of about $4000 \mathrm{yr} \mathrm{BP}$ for the truncation of zone KRB2. It is recognised that the assumption of uniformity in sedimentation rate is not likely to represent realiry for sites adjacent to a large river in which ephemeral sedimentation influxes are more likely than gradual accumulation. The Nothofagus maximum and high values of Pomaderris apetala are known to characterise early-middle Holocene pollen sequences from western Tasmania (Macphail 1979, 1983). The Nothofagus maximum is usually attained by ca. $7000 \mathrm{yr}$ $\mathrm{BP}$ but appears to be slightly later here. However, the values of $P$. apetala recorded in Zone KRB2 and occurence of the Nothofagus maximum are consistent with a middle Holocene age for the sediments.

It is difficult to judge the duration of the period when the slope deposits/fan gravels accumulated. Some of the pollen curves show marked discontinuity in values, e.g. Phyllocladus, Bauera, Epacridaceae and Melaleuca, while others show remarkable continuity, e.g. Eucalyptus, Monotoca and Agastachys. Some temporal hiatus must be implied by sharp discontinuity, while continuous curves do not necessarily demonstrate temporal continuity. However, the estimated age of the top of the silt at ca. $4000 \mathrm{yr} \mathrm{BP}$ and the dated base of the peaty soil at $2520 \pm 80 \mathrm{yr}$ BP (SUA 2597) suggests an interval of perhaps $\approx 1500$ years.

During the last 2500 years represented by KRB1, Phyllocladus was the dominant wet forest taxon with Eucalyptus and Nothofagus. Together these taxa indicate the occurrence of wet mixed forest, while the relative abundance of Lagarostrobos franklinit, Agastachys and Monotoca suggests strong presence of riparian forest and wet scrub vegetation. It is notable that this site is very close to the upstream limit of Lagarostrobos in the King Valley today, whereas at Smelter Creek, less than $1 \mathrm{~km}$ to the south, Lagarostrobos expanded at around $5000 \mathrm{yr} \mathrm{BP}$, and at Governor Bog, $2 \mathrm{~km}$ to the south, around $11000 \mathrm{yr} \mathrm{BP}$ (Colhoun et al. $1991 \mathrm{a}, \mathrm{b})$. The increased Proteaceae and Tasmannia indicate a greater diversity of shrubs which could have resulted from several factors including increased burning, flooding, change of substrate from silt to peaty soil or possibly even reduction in temperature. However, the data are insufficient to determine the cause of the change noted in the pollen assemblage.

The counts of charcoal particles over $20 \mu \mathrm{m}$ size indicated that fire was present throughout the period. The highest values of 510 to $622 \times 10^{3}$ grains/gram occur in the top $5 \mathrm{~cm}$ and indicate the recent high intensity/frequency of burning. Throughout the rest of the profile, values generally vary from 0.9 to $178 \times 10^{3}$ grains/gram except at $100 \mathrm{~cm}$ where $401 \times 10^{3}$ grains/gram were recorded. The mean 
value is 125.7 and standard deviation 144.5 . The very high surface values coincide with the period of European exploitation of the valley. The lowest values, 0.9 to $9.8 \times$ $10^{3}$ grains/gram, occur below $160 \mathrm{~cm}$ and coincide with the alpine herbfield and Microstrobos heath vegetation. Throughout the rest of the profile, there is no correlation between charcoal concentration and the wet forest vegetation, which developed and was modified despite repeated firing.

\section{CONCLUSION}

The short sequence of pollen-bearing sediment from King River Bridge appears to extend from late glacial to modern time, with a short interruption occasioned by the deposition of slope (landslide?) and alluvial fan gravels. Comparison with Governor Bog suggests that the alpine heathland and herbland of Zone KRB4 was developed before $13000 \mathrm{yr}$ BP and that the climate was cold and wet. After $13000 \mathrm{yr}$ BP the rainforest taxa Phyllocladus and Nothofagus expanded in Zone KRB3 and the vegetation was a mosaic of rainforest/ wet mixed forest, scrub, heath and sedge communities adjacent to the King River until about $6400 \mathrm{yr}$ BP. After $6400 \mathrm{yr} \mathrm{BP}$, Phyllocladus declined and the wet mixed forest understorey was co-dominated by Nothofagus and Eucalyptus in Zone KRB2. The forest understorey appears to have become more diverse, and scrub, heath and sedge communities also occurred in what was probably a mosaic of vegetation communities close to the flood-prone margins of the King River. During the last 2500 years the wet mixed forest was again dominated by Phyllocladuswhile Lagarostrobosexpanded to its uppermost point along the course of the King River. The co-occurrence of Agastachys, Proteaceae and Tasmannia suggests that wet scrub vegetation was more important than sclerophyll heath and scrub. After 13000 yr BP the climate appears to have been always cool and wet, and favourable for the development of temperate rainforest. The complexity of the pollen assemblages suggests the maintenance of a mosaic of vegetation communities adjusted to the effects of sediment variation, flooding and waterlogging adjacent to the King River and to burning throughout the Holocene.

\section{ACKNOWLEDGEMENTS}

The authors thank Dennis Charlesworth, University of Tasmania, for preparing the pollen samples and Mrs Margaret Lane, University of Newcastle, for word processing the manuscript.

\section{REFERENCES}

Colmoun, E.A. \& Frizsmons, S.J., 1990: Iate Cainozoic glaciation in western Tasmania, Auscralia. Quat. Sci. Rev. 9: 199-216.

Colhoun, E.A., van de Gefr, G. \& Fitzsmons, S.J., 1991a: Late glacial and Holocene vegetation history at Governor Bog, King Valley, western Tasmania. J. Quat. Sci. 6(1): 55-66.

Colholn, E.A., van De GreR, G. \& Fitzsimons, S.J., 199 lb: Late Quaternary organic deposits at Smelrer Creek and vegetation history of the middle King Valley, western Tasmania. $J$. Biogeogr. 18: 1-11.

CURT15, W.M., 1963, 1967: THE STUDENT'S FLORA OF TASMANIA, PARTS 2 AND 3. Government Printer, Hobart.

CurTIS, W.M. \& Morris, D.I., 1975: THE STUDENT'S FLORA OF TASMANLA, 2ND EDN, PART 1. Government Printer, Hobart.

FAFGRI, K. \& IVERSEN, J., 1975: TEXTBOOK OF POLLEN ANALYSIS. 3rd Edn, Munksgaard, Copenhagen.

Fitzsimons, S.J., 1988: The Quaternary Stratigraphy of the King Valley. Unpubl.PhD Thesis, University of Tasmania.

KIRKPATRICK, J.B., 1977: The impact of man on the vegetation of the West Coast Region. In Banks, M.R. \& Kirkpatrick, J.B. (Eds): LANDSCAPE AND MAN. Royal Society of Tasmania, Hobart: I51-156.

MacPHAIt, M.K., 1975: Late Pleistocene environments in Tasmania. Search 6(7): 295-300.

MacPhail, M.K., 1979: Vegetation and climates in southern Tasmania since the last glaciation. Quat. Res. 11: 306-341.

MAcphall, M.K. 1983: The early to middle Holocene Pomaderris maximum in southeastern Australia. In Chappell, J.M.A. \& Grindrod, A. (Eds): PROCEEEDINGS OF THE FIRST CLIMANZ CONFERENCE. Howman's Gap, 1981. Department of Biogeography and Geomorphology, Research School of Pacific Studies, Australian National University, Canberra: 105-106.

STOCKMARR, J., 1971: Tablets with spores used in absolute pollen analysis. Pollen et Spores 13: 615-621.

WAKLFIELD, N.A., 1975: FERNS OF VTCTORLAAND TASMANLA. Field Naturalists Club of Victoria, Griffin Press, Adelaide: $80 \mathrm{pp}$.

WuIIS, J.H., 1970: A HANDBOOK OF PLANTS OF VICTORIA. VOL. $I$ (FERNS, CONIFERS AND MONOCOTYLEDONS). 2nd Edn, Melbourne University Press: $481 \mathrm{pp}$.

(accepted 9 August 1991) 